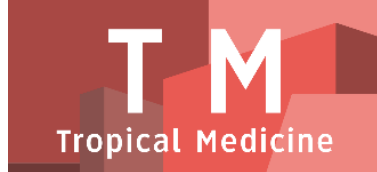

PAPER - OPEN ACCESS

Uji Aktivitas Antioksidan Kombinasi Ekstrak Etanol Rimpang Temu Giring (Curcuma Heyneana) dan Daun Pugun Tanoh (Curanga Fel-Terrae) Menggunakan Metode Diphenyl Picrylhydrazil(DPPH)

$\begin{array}{ll}\text { Author } & : \text { Marianne Marianne } \\ \text { DOI } & : 10.32734 / \text { tm.v1i2.223 } \\ \text { Electronic ISSN } & : 2623-0550 \\ \text { Print ISSN } & : 2623-0542\end{array}$

Volume 1 Issue 2 - 2018 TALENTA Conference Series: Tropical Medicine (TM)

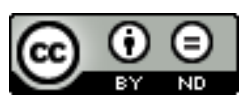

This work is licensed under a Creative Commons Attribution-NoDerivatives 4.0 International License.

Published under licence by TALENTA Publisher, Universitas Sumatera Utara
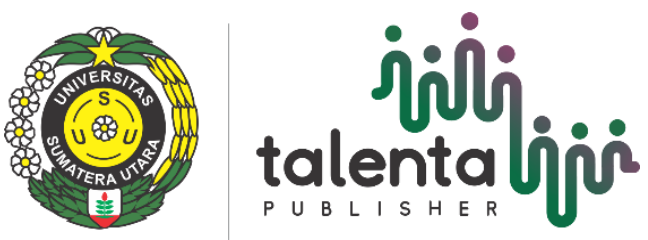


\title{
Uji Aktivitas Antioksidan Kombinasi Ekstrak Etanol Rimpang Temu Giring (Curcuma Heyneana) dan Daun Pugun Tanoh (Curanga Fel-Terrae) Menggunakan Metode Diphenyl Picrylhydrazil(DPPH)
}

\author{
Marianne $^{\mathrm{a}}$, Popi Patilaya ${ }^{\mathrm{a}}$, Bobby Trianda Barus ${ }^{\mathrm{a}}$ \\ ${ }^{a}$ Fakultas Farmasi, Universitas Sumatera Utara, Medan, Indonesia
}

anne_aceh@yahoo.com

\begin{abstract}
Abstrak
Pugun tanoh(Curanga fel-terrae) merupakan salah satu jenis tumbuhan yang diketahui memilki banyak khasiat dan telah digunakan secara empiris oleh masyarakat Kabupaten Karo. Temu giring merupakan salah satu dari sekian banyak tanaman obat yang tumbuh di Indonesia. Telah dilakukan beberapa penelitian tentang khasiat temu giring yaitu sebagai immunodulator, aktivitas fagositosis dan penurun kadar kolesterol darah. Tujuan penelitian ini adalah untuk mengetahui aktivitas antioksidan kombinasi ekstrak etanol daun pugun tanoh dan rimpang temu giring. Serbuk simplisia daun pugun tanoh dan rimpang temu giringdiekstraksi dengan cara maserasi menggunakan pelarut etanol 96\%. Masing-masing ekstrak dan kombinasi ekstrak diuji aktivitasantioksidan terhadap DPPH sebagai radikal bebas dengan mengukur absorbansi DPPH pada panjang gelombang $516 \mathrm{~nm}$ pada menit ke-35. Hasil pengujian aktivitas antioksidan dengan metode DPPH menunjukkan bahwa ekstrak etanol daun pugun tanoh tunggal, rimpang temu giring tunggal, beserta kombinasinya (1:1, 1:2 dan 2:1) memiliki aktivitas antioksidan dengan nilai

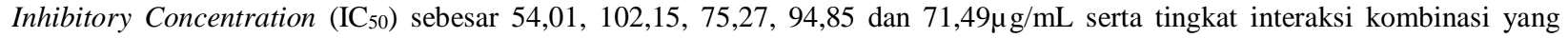
dihasilkan adalah aditif, aditif dan antagonis menengah dengan nilai Combination Index sebesar 1,09, 1,03dan 1,21. Kesimpulan yang diperoleh dari hasil pengujian antioksidan menunjukkan bahwa ekstrak etanol rimpang temu giring dan daun pugun tanoh memiliki aktivitas antioksidan yang kuat, tetapi kurang efektif bila kedua ekstrak dikombinasikan..
\end{abstract}

Keywords: uji aktivitas antioksidan; Curanga fel-terrae, Cucuma heyneana; DPPH

\section{Pendahuluan}

Dalam kehidupan sehari-hari, kita tidak dapat terbebas dari senyawa radikal bebas. Asap rokok, makanan yang digoreng, dibakar, paparan sinar matahari berlebih, asap kendaraan bermotor, obat-obat tertentu, racun dan polusi udara merupakan beberapa sumber pembentuk senyawa radikal bebas [1]. Radikal bebas peranan penting dari beberapa patofisiologi berbagai penyakit seperti penyakit hati, iskemia, kanker dan berbagai penyakit kronis lainnnya [2]. Selain itu radikal bebas juga diketahui sebagai salah satu penyebab kerusakan dan kematian sel dengan cara berikatan dengan elektron molekul sel [2]. Sebagai upaya untuk melindungi diri dari radikal, tubuh menghasilkan senyawa antioksidan endogen tetapi bila jumlah radikal bebas melebihi jumlah antioksidan dalam tubuh, kelebihannya akan menyerang komponen lipid, protein ataupun DNA [3]. Pertahanan dari dalam tubuh seringkali berkurang akibat pengaruh lingkungan dan pola hidup yang buruk.Pada kondisi ini manusia membutuhkan senyawa antioksidan yang diperoleh dari luar tubuh seperti buah dan sayur yang pada umumnya mengandung nutrisi dan senyawa yang mampu berperan sebagai antioksidan $[4,1]$. 
Penggunaan bahan-bahan alami yang memiliki aktivitas biologis yang mendorong penelitian lebih lanjut, setelah senyawa sintetis yang memiliki aktivitas biologis seperti Butylated Hydroxy Toluen (BHT), Butylated Hydroxy Anysole (BHA), TertButylHydroxyQuinone (TBHQ) terbatas dikarenakanmemiliki sifat karsinogenik [5] yang dikhawatirkan dapat menimbulkan efek samping yang merugikan, hal ini mendorong antioksidan alami menjadi alternatif yang dibutuhkan $[4,6,7]$.

Temu giring merupakan salah satu dari sekian banyak tanaman obat yang tumbuh di Indonesia, tanaman ini memiliki kandungan khas kurkumin yang berguna sebagai antioksidan [8]. Begitu juga dengan daun pugun tanoh, tanaman ini memiliki kandungan senyawa flavonoid [9]. Komponen flavonoid telah banyak dilaporkan perannya sebagai antioksidan [10]. Kombinasi dari dua jenis antioksidan mungkin dapat menghasilkankan potensi aktivitas total antioksidan yang lebih tinggi, yang dikenal dengan efek sinergisme. (11).

Penggunaan kombinasi herbal (poliherbal) telah digunakan dalam praktek obat-obatan sejak ribuan tahun yang lalu untuk meningkatkan efek terapeutik. Beberapa tumbuhan memiliki efek sinergis terhadap tumbuhan lain , dan beberapa memiliki efek pelengkap dengan tumbuhan lain [12,13]

Berdasarkan uraian diatas, penulis merasa penting dan perlu untuk meneliti aktivitas antioksidan ekstrak etanol rimpang temu giring yang dikombinasi dengan daun puguntanohdengan menggunakan metode pemerangkapan radikal bebas DPPH, yang diharapkan dapat menjadi sumber informasi pengembangan obat baru yang efektif digunakan untuk menangkal radikal dengan kombinasi kedua ekstrak tersebut.

\section{Bahan dan Metode}

\subsection{Lokasi Penelitian}

Penelitian ini dilakukan di Laboratorium Penelitian Fakultas Farmasi Universitas Sumatera Utara.

\subsection{Metode}

Penelitian ini dilaksanakan pada bulan Agustus sampai dengan bulan Oktober 2016

\subsection{Alat dan Bahan}

Alat dan bahan yang digunakan dalam penelitian ini adalah alat-alat gelas laboratorium, Spektrofotometer UVVis (Shimadzu) rimpang temu giring, daun pugun tanoh, vitamin C (Sigma-Aldrich), 1,1-diphenyl-2-picrylhydrazyl (Sigma Aldrich), metanol (Merck).

\subsection{Identifikasi Tumbuhan}

Identifikasi tumbuhan dilakukan di Herbarium Bogoriense, Bidang Botani, Pusat Penelitian dan Pengembangan Biologi, Lembaga Ilmu Pengetahuan Indonesia Bogor

\subsection{Skrinning Fitrokimia}

Skrining fitokimia serbuk simplisia rimpang temu giring dan daun pugun tanoh meliputi pemeriksaan senyawa alkaloida, glikosida, saponin (Depkes, RI., 1995); flavonoid, tanin, dan triterpenoid/ steroid (Fransworth, 1966).

\subsection{Pembuatan Ekstrak Etanol}

Serbuk simplisia rimpang temu giring/daun puguntanoh dimaserasi dengan etanol $96 \%$ selama 7 hari sambil sekali-sekali diaduk, kemudian disaring, dan filtrat yang diperoleh dikeringkan dengan alat penguap putar [14].

\subsection{Pengujian Aktivitas Antioksidan dengan Metode Peredaman DPPH}

Kemampuan sampel uji dalam meredam radikal bebas DPPH dilihat dari perubahan warna DPPH dari ungu menjadi kuning dengan nilai IC50 (konsentrasi sampel uji yang mampu meredam radikal bebas sebanyak 50\%)yang digunakan sebagai parameter untuk menilai aktivitas antioksidan sampel uji [15].

\subsection{Pembuatan Larutan Induk DPPH dan Pengukuran Larutan DPPH}


Ditimbang 20 mg DPPH, dimasukkan kedalam labu tentukur $100 \mathrm{ml}$, dilarutkan dengan metanol lalu volumenya dicukupkan dengan metanol sampai garis tanda (200 ppm). Dipipet larutan DPPH 200 ppm sebanyak $5 \mathrm{~mL}$ kemudian dimasukkan ke dalam labu tentukur $25 \mathrm{~mL}$, dicukupkan dengan metanol sampai garis tanda (konsentrasi $40 \mathrm{ppm})$. Pengukuran dilakukan pada panjang gelombang 400-800 $\mathrm{nm}$.

\subsection{Pembuatan Larutan Induk Ekstrak}

Sebanyak $25 \mathrm{mg}$ masing-masing ekstrak etanol rimpang temu giring dan daun pugun tanoh ditimbang, dimasukkan ke dalam labu tentukur $25 \mathrm{~mL}$, dilarutkan dengan metanol lalu volumenya dicukupkan dengan metanol sampai garis tanda (konsentrasi $1000 \mathrm{ppm}$ ).

\subsection{Pembuatan Larutan Induk Vitamin C}

Sebanyak 2,5 mg serbuk vitamin C ditimbang, dimasukkan ke dalam labu tentukur $25 \mathrm{~mL}$, dilarutkan dengan metanol lalu volumenya dicukupkan dengan metanol sampai garis tanda (konsentrasi $100 \mathrm{ppm}$ ).

\subsection{Pembuatan Larutan Induk Katekin}

Sebanyak 2,5 mg serbuk katekin ditimbang, dimasukkan ke dalam labu tentukur $25 \mathrm{~mL}$, dilarutkan dengan metanol lalu volumenya dicukupkan dengan metanol sampai garis tanda (konsentrasi $100 \mathrm{ppm}$ ).

\subsection{Pengukuran Aktivitas Antioksidan}

LI ekstrak masing-masing dipipet sebanyak $0,5 \mathrm{~mL} ; 1,0 \mathrm{~mL} ; 1,5 \mathrm{~mL}$; dan 2,0 mL ke dalam labu tentukur $25 \mathrm{~mL}$ untuk mendapatkan konsentrasi larutan uji 20 ppm, 40 ppm, 60 ppm, dan 80 ppm untuk larutan uji ekstrak etanol tunggal.

LI ekstrak masing-masing dipipet sebanyak $0,25 \mathrm{~mL} ; 0,5 \mathrm{~mL} ; 0,75 \mathrm{~mL}$; dan $1,0 \mathrm{~mL}$ ke dalam labu tentukur 25 $\mathrm{mL}$ untuk mendapatkan konsentrasi larutan uji 20 ppm, 40 ppm, 60 ppm, dan 80 ppm untuk larutan uji kombinasi ekstrak dengan perbandingan 1:1.

LI ekstrak dipipet masing-masing 0,25:0,5 mL;0,5:1,0 mL; 0,75:1,5 mL dan 1,0:2,0 mL untuk mendapatkan konsentrasi campuran larutan uji 30 ppm, 60 ppm, 90 ppm dan 120 ppm untuk larutan uji kombinasi ekstrak dengan perbandingan 1:2

LI ekstrak dipipet masing-masing 0,5:0,25 mL; 1,0:0,5 mL; 1,5:0,75 mL dan 2,0:1,0 mL untuk mendapatkan konsentrasi campuran larutan uji 30 ppm, 60 ppm, 90 ppm dan 120 ppm untuk larutan uji kombinasi ekstrak dengan perbandingan 2:1.

LI vitamin $\mathrm{C}$ dipipet sebanyak $0,25 \mathrm{~mL} ; 0,5 \mathrm{~mL} ; 1,0 \mathrm{~mL}$; dan $2,0 \mathrm{~mL}$ ke dalam labu tentukur $25 \mathrm{~mL}$ untuk mendapatkan konsentrasi larutan uji 1 ppm, 2 ppm, 4 ppm, dan 8 ppm.

LI katekin dipipet sebanyak $0,25 \mathrm{~mL} ; 0,5 \mathrm{~mL} ; 0,75 \mathrm{~mL}$; dan $1,0 \mathrm{~mL}$ ke dalam labu tentukur $25 \mathrm{~mL}$ untuk mendapatkan konsentrasi larutan uji 1 ppm, 2 ppm, 3 ppm, dan 4 ppm.

Kemudian ditambahkan $5 \mathrm{~mL}$ larutan DPPH 200 ppm ke dalam masing-masing labu tentukur diatas, lalu volumenya dicukupkan dengan metanol sampai garis tanda. Pengukuran dilakukan setelah didiamkan selama 35 menit pada panjang gelombang $516 \mathrm{~nm}[15]$.

\subsection{Penentuan Persen Peredaman}

Kemampuan antioksidan diukur sebagai penurunan serapan larutan DPPH akibat adanya penambahan sampel. Nilai serapan larutan DPPH sebelum dan sesudah penambahan ekstrak dihitung sebagai persen peredaman (\%peredaman) dengan rumus sebagai berikut:

$\%$ peredaman $=\frac{A_{\text {kontrol }}-A_{\text {sampel }}}{A_{\text {kontrol }}} \times 100 \%$
Keterangan:

$\mathrm{A}_{\text {kontrol }}=$ Absorbansi tidakmengandung sampel

$\mathrm{A}_{\text {sampel }}=$ Absorbansi sampel 
Selanjutnya hasil perhitungan dimasukkan ke dalam persamaan regresi dengan konsentrasi ekstrak (ppm) sebagai absis (sumbu X) dan nilai \% peredaman (antioksidan) sebagai ordinatnya (sumbu Y) [15].

\subsection{Analisis Efektivitas Kombinasi Ekstrak}

Data dari hasil pengukuran menggunakan alat Spektrofotometer UV-Vis dianalis menggunakan perangkat lunak CompuSyn untuk menentukan nilai Combination Index (CI) yang digunakan sebagai parameter interaksi kombinasi antar kedua ekstrak pada rentang sinergis sampai dengan antagonis, dimana data yang dimaksudkan adalah konsentrasi sebagai dosis dan absorbansi sebagai efek pada perangkat lunak CompuSyn [16].

\section{Hasil}

Skrining fitokimia serbuk simplisia dilakukan untuk menentukan senyawa metabolit sekunder yang terkandung pada masing-masing serbuk simplisia, hasil skrining fitokimia serbuk simplisia masing-masing tumbuhan dapat dilihat pada Tabel 1

Table 1. Hasil skrining fitokimia serbuk simplisia

\begin{tabular}{llcc}
\hline No & Senyawa & $\mathrm{CF}$ & $\mathrm{CH}$ \\
\hline 1. & Alkaloid & - & - \\
2. & Flavanoid & + & + \\
3. & Tanin & + & - \\
4. & Saponin & + & + \\
5. & Glikosida & + & + \\
6. & Triterpenoid dan steroid & + & + \\
\hline
\end{tabular}

Keterangan:

$(+)$ : terdapat senyawa

(-) : tidak terdapat senyawa

\section{CF : Curanga fel-terrae \\ $\mathrm{CH}$ : Curcumaheyneana}

Aktivitas antioksidan kombinasi ekstrak etanol rimpang temu giring dan daun pugun tanoh di hasilkan dari pengukuran radikal bebas DPPH dengan penambahan larutan ekstrak etanol rimpang temu giring dan daun pugun tanoh dengan beberapa perbandingan $(1: 1,1: 2$ and 2:1) menggunakan Spektrofotometer UV-Vis. Hasil aktivitas antioksidan dapat dilihat pada Tabel 2, 3, dan 4 .

Table 2. Hasil analisis aktivitas antioksidan kombinasi ektrak etanol rimpang temu giring dan daun pugun tanoh dengan perbandingan 1:1 beserta pengujian ekstrak tunggalnya

\begin{tabular}{ccccc}
\hline No & Konsentrasi (ppm) & $\begin{array}{c}\text { \% Peredaman } \\
\text { Ekstrak etanol CH } \\
\text { (tunggal) }\end{array}$ & $\begin{array}{c}\text { Kombinasi ekstrak etanol } \\
\text { dari CH dan CF (1:1) }\end{array}$ \\
\hline 1. & 20 & 19,31 & 9,93 & 14,56 \\
2. & 40 & 86,33 & 21,64 & 27,85 \\
3 & 60 & 55,79 & 29,32 & 39,17 \\
4 & 80 & 73,68 & 36,58 & 50,85 \\
\hline
\end{tabular}


Table 3. Hasil analisis aktivitas antioksidan kombinasi ekstrak etanol rimpang temu giring dan daun pugun tanoh dengan perbandingan 2:1 dan $1: 2$

\begin{tabular}{lccc}
\hline No & Konsentrasi (ppm) & \multicolumn{2}{c}{$\%$ Peredaman } \\
& & $\begin{array}{c}\text { Kombinasi ekstrak etanol } \\
\text { CH dan CF }(2: 1)\end{array}$ & $\begin{array}{c}\text { Kombinasi ekstrak etanol } \\
\text { CH dan CF (1:2) }\end{array}$ \\
\hline 1. & 30 & 17,35 & 24,61 \\
2 & 60 & 31,20 & 43,05 \\
3. & 80 & 45,17 & 62,65 \\
4. & 120 & 64,34 & 79,19 \\
\hline
\end{tabular}

Table 4. Hasil persamaan regresi dan nilai $\mathrm{IC}_{50}$ dari pengujian antioksidan ekstrak tunggal dan kombinasi ekstrak rimpang temu giring dan daun pugun tanoh

\begin{tabular}{llcc}
\hline No & Larutan Uji & Persamaan regresi & $\mathrm{IC}_{50}(\mathrm{ppm})$ \\
\hline 1. & Ekstrak etanol CF (tunggal) & $\mathrm{Y}=0,92645 \mathrm{x}-0,0360$ & 54,01 \\
2. & Ekstrak etanol CH (tunggal) & $\mathrm{Y}=0,49086 \mathrm{x}-0,1404$ & 102,15 \\
3 & Kombinasi ekstrak etanol CF dan CH (1:1) & $\mathrm{Y}=0,66652 \mathrm{x}-0,1748$ & 75,27 \\
4. & Kombinasi ekstrak etanol CF dan CH (1:2) & $\mathrm{Y}=0,52761 \mathrm{x}-0,0446$ & 94,85 \\
5. & Kombinasi ekstrak etanol CF dan CH (2:1) & $\mathrm{Y}=0,66695 \mathrm{x}-0,1870$ & 71,49 \\
\hline
\end{tabular}

\section{Keterangan:}
$\mathrm{CF}$ : Curanga fel-terrae
$\mathrm{IC}_{50}$ : Inhibitor Concentration50\%

$\mathrm{CH}$ : Curcuma heyneana

Hasil analisis efektivitas kombinasi ektrak etanol menggunakan perangkat lunak CompuSyn

Analisis efektivitas aktivitas antioksidan kombinasi ekstrak etanol menggunakan perangkat lunak CompuSyn dengan nilai Combination Index sebagai parameter analisis dapat dilihat pada Tabel 5

Table 5. Nilai Combination Index (CI) menggunakan perangkat lunak CompuSyn

\begin{tabular}{ccc}
\hline EERCH:EEDCF & Nilai CI & Deskripsi \\
\hline $1: 1$ & 1,09 & Aditif \\
$1: 2$ & 1,03 & Aditif \\
$2: 1$ & 1,21 & Antagonis menengah
\end{tabular}

Keterangan:
EERCH
EEDCF

CI : Combination Index

\section{Pembahasan}

Hasil skrining fitokimia diketahui bahwa rimpang temu giring dan daun pugun tanoh memiliki potensi sebagai antioksidan dengan adanya senyawa yang mempunyai potensi sebagai antioksidan yaitu tanin, flavonoid. Senyawa tersebut bertindak sebagai penangkap radikal bebas karena gugus hidroksil yang dikandungnya mendonorkan hidrogen kepada radikal bebas [17].

Hasil analisis peredaman radikal bebas oleh ekstrak tunggal daun pugun tanoh dan rimpang temu giring beserta kombinasinya menunjukkan bahwa kenaikan konsentrasi berbanding lurus dengan peningkatan persen peredaman karena semakin banyak atom hidrogen dari ekstrak etanol daun pugun tanoh atau rimpang temu giring yang 
berpasangan dengan elektron pada radikal bebas DPPH sehingga serapansemakin menurun yang ditandai dengan berubahnya warna larutan menjadi kuning [15].

Hasil pada Tabel 4 menunjukkan bahwa ekstrak etanol tunggal, kombinasi EEDCF dan EERCH $(1: 1 ; 1: 2 ; 2: 1)$ dan pembanding memiliki aktivitas antioksidan yang berbeda satu dengan yang lain. Perbedaan nilai $\mathrm{IC}_{50}$ pada masing-masing ekstrak ataupun kombinasi ekstrak disebabkan oleh adanya distribusi jenis dan jumlah golongan senyawa metabolit sekunder yang bersifat sebagai antioksidan berdasarkan kepolaran pelarut yang digunakan [18]. Menurut Harborne (1996) etanol dapat menarik senyawa alkaloid, steroid, saponin, flavonoid, antakuinon, dan glikosida [19].

Kombinasi ekstrak etanol rimpang temu giring dan daun pugun tanoh (1:2) pada pengujian kombinasi ekstrak etanol memiliki nilai $\mathrm{IC}_{50}$ yang paling rendah dengan nilai $\mathrm{IC}_{50} 71.49 \mathrm{ppm}$. Kombinasi ekstrak tersebut memiliki aktivitas antioksidan yang lebih tinggi dibandingan dengan perbandingan yang lain dikarenakan komponen polifenol seperti flavonoid, polifenol atau flavonoid berperan penting pada aktivitas antioksidan, juga memiliki peran dalam mencegah oksidasi lipid [20].

Berdasarkan hasil analisis efektivitas kombinasi ekstrak menggunakan perangkat lunak CompuSyn pada Tabel 5 menunjukkan bahwa kombinasi ekstrak etanol rimpang temu giring dan daun pugun tanoh (1:1 and 1:2) memberikan efek aditif bila dikombinasikan, yang berarti penggunaan kedua ekstrak tersebut secara bersamaan dengan perbandingan 1:1 dan 1:2 memiliki pengaruh peningkatan aktivitas antioksidannya dari salah satu atau kedua ekstrak yang dikombinasikan [21]. Sedangkan pada EERTG dan EEDPT (2:1) memberikan efek antagonis menengah yang berarti memberikan efek penurunan terhadap aktivitas antioksidannya dalam meredam radikal bebas DPPH. Pengaruh tersebut terjadi diduga akibat interaksi antara senyawa-senyawa kimia yang terkandung pada masing-masing ekstrak. Secara teori pada tanaman obat, selain zat aktif sebagai komponen utama yang paling berpengaruh, masih terdapat senyawa-senyawa sampingan lain, mungkin dapat mempengaruhi respon yang diharapkan [22].

Dalam ekstrak etanol terdapat senyawa metabolit sekunder seperti: glikosida, saponin, alkaloida dan lain-lain. Senyawa-senyawa tersebut akan mempengaruhi hasil respon. Pada konsentrasi kecil, senyawa-senyawa sampingan tersebut masih terdapat dalam jumlah yang kecil dan belum mempengaruhi atau mengganggu hasil yang diharapkan. Pada konsentrasi yang lebih besar, efek dari senyawa-senyawa sampingan tersebut menjadi besar secara perbandingan sehingga mulai berpengaruh dan mengganggu respon. Hal ini terjadi pada konsentrasi tinggi, senyawa-senyawa sampingan akan mengganggu hasil respon yang diharapkan [22].

Dengan dikombinasikan dua jenis ekstrak, yang masing-masing mempunyai senyawa metabolit sekunder, akan saling berinteraksi. Mungkin berefek potensiasi pada konsentrasi yang kecil, mungkin juga sebaliknya yaitu saling melemahkan. Selain itu perlu juga menjadi pertimbangan bahwa pada konsentrasi yang terlalu tinggi, antioksidan yang berlebih dapat berubah menjadi prooksidan. Oleh karena itu, pada konsentrasi yang lebih tinggi, respon antioksidan belum tentu menjadi lebih baik. Hal ini perlu diteliti lebih lanjut.

\section{Kesimpulan dan Saran}

Ekstrak etanol rimpang temu giring dan daun pugun tanoh memiliki aktivitas antioksidan yang sedang-kuat yang ditandai dengan nilai IC50 (Inhibitor Concentration 50\%)yang diperoleh pada pengujian ekstrak tunggal (102,15 dan 54,01) tetapi kurang efektif bila dikombinasikan, yang ditandai dengan nilai CI (Combination Index) yang diperolehdengan perbandingan 1:1, 1:2 dan 2:1.

Saran saya kepada peneliti selanjutnya untuk melakukan kombinasi isolat murni yang berkhasiat sebagai antioksidan dari rimpang temu giring dan daun pugun tanoh. 


\section{Referensi}

[1] Pietta, P-G. Flavonoids as Antioxidants. J. Nat. Prod 1999;63:1035-1042.

[2] Majewska M, Skrzycki M, Podsiad M, Czeczot H. Evaluation of antioxidant potential of flavonoids: an in vitro study. Acta Pol Pharm 2011;68:611-5.

[3] Halliwell B, Gutteridge J. Free Radicals in Biology and Medicine. 4th ed. Oxford: Oxford University Press; 2007.

[4] Parr AJ, Bolwell GP. Phenols in plant and in man. The potential for possible nutritional enhancement of the diet by modifying the phenols content or profile. J Sci Food Agric2000;80:985-1012.

[5] Benhammou N, Atik Bekkara F, Panovska TK. Antioxidant and antimicrobial activities of the Pistacialentiscus and Pistaciaatlantica extracts. Afr J Pharm Pharmacol 2008;2:22-8.

[6] Rohdiana, D. Aktivitas Daya Tangkap Radikal Polifenol Dalam Daun Teh. Majalah Jurnal Indonesia 2001;12(1):53-58.

[7] Sunarni, T. Aktivitas Antioksidan Penangkap Radikal Bebas Beberapa Kecambah dari Biji Tanaman Familia Papilionaceae. Jurnal Farmasi Indonesia 2005;(2):53-61.

[8] Lukiati, B., Aulanni'am, Darmanto, W. The Effects of Curcuma heyneana Ethanolic Extract on theSuperoxide Dismutase Activity and Histological Pancreas of Type1 Diabetes Mellitus Rats. International Journal of Basic \& Applied Sciences 2012;2:29.

[9] Harahap, U., Patilaya, P., Marianne, Yuliasmi, S., Husori, D.I., Prasetyo, B.E., Laila, L., Sumantri, I.B., dan Wahyuni, H.S. Profil Fitokimia Ekstrak Etanol Daun Puguntano [Curanga fel-terrae (Merr.) Lour.] yang Berpotensi Sebagai Antiasma. Prosiding Seminar Nasional Sains dan Teknologi V Lembaga Penelitian Universitas Lampung 2013:422-426.

[10] Winarsi, H. Antioksidan Alami dan Radikal Bebas. Yogyakarta: Penerbit Kanisius; 2007. Halaman 18.

[11] Lingga, L. The Healing Power of Anti-oxidant. Jakarta: Elex Media Komputindo; 2012.

[12] Badejo AA, Damilare A, Ojuade TD. Processing effects on the antioxidant activities of beverage blends developed from Cyperus esculentus, Hibiscus sabdariffa, and Moringa oleifera extracts. Prev Nutr Food Sci 2014;19:227, 33.

[13] Wasito H, Ekowati H, Hayati FF. In Vitro antioxidant activity of Zingiber officinale, Piper retrofractum, and their combinations. Indones J Cancer Chemoprevention 2011;2:295-8.

[14] DitjenPOM RI. Farmakope Indonesia. Edisi Ketiga. Jakarta: Departemen Kesehatan RI; 1979.

[15] Molyneux P. The use of the stable free radical diphenylpicrylhydrazyl (DPPH) for estimating antioxidant activity. Songklanakarin J. Sci. Technol 2004;26(2):211-219.

[16] Chou, T. C. Theoretical basis, experimental design, and computerized simulation of synergism and antagonism in drug combination studies. PharmacolRev 2006;58(3):621-681.

[17] Heim KE, Tagliaferro AR, Bobilya DJ. Flavonoid antioxidants: Chemistry, metabolism and structure-activity relationships. J Nutr Biochem 2002;13:572-84.

[18] Huliselan, Y., dan Defny S.W.Aktivitas Antioksidan Ekstrak Etanol, Etilasetat, dan n-Heksan dari Daun Sesewanua (Clerodendron Squamatum Vahl.). Pharmacon Jurnal Ilmiah Farmasi2015;4(3):155-163.

[19] Harborne JB. Metode Fitokimia. Ed ke -2. Padmawinata K, Soediro I, penerjemah. Bandung: ITB Press. Terjemahan dari: Phytochemical Method; 1996.

[20] Sannigrahi, S., Upal, K.M., Dilip, K.P., Sambit, P., dan Sourabh, J. Antioxidant Potential of Crude Extract and Different Fractions of Enhydra fluctuans Lour. Iranian Journal of Pharmaceutical Research2010;9(1):75-82.

[21] Joyce, L dan Kee, E.,R. Farmakologi : Pendekatan Proses Keperawatan. Peter Anugrah, penerjemah. Jakarta: EGC; 1996. Halaman 142.

[22] Hidayat, M. Aktivitas Ekstrak Protein Biji Kedelai (Glycine Max L. Merr) Varietas Detam 1 terhadap Pengendalian Berat Badan Dan Peningkatan Kadar Kolesistokinin Melalui Mekanisme Aktivitas Mitogen Activated Protein Kinase (MAPK) pada Tikus Wistar Jantan. Universitas Padjadjaran: Disertasi; 2011. 